\title{
National Standards of Education affect the emplotment opportunities of vocational high school graduates
}

\author{
Eka Hendi Andriansyah * iD, Putri Ulfa Kamalia \\ Universitas Negeri Surabaya. \\ * Corresponding Author. Email: ekaandriansyah@unesa.ac.id
}

\section{ARTICLE INFO}

\section{Article History}

Received:

18 May 2021;

Revised:

13 June 2021:

Accepted:

27 June 2021;

Available online:

31 October 2021

\section{Keywords}

National Standards of

Education;

Graduate employment

opportunities;

Vocational high

schools

\begin{abstract}
This study aims to find out the National Standard of Education indicators that are the most dominant in influencing vocational schools, especially in producing the expected outcomes. The research is aimed at vocational schools in the field of economics and finance in the city of Surabaya. The data collection includes NSE assessment data from BAN-SM and employment opportunities from 22 schools. The object of further research is processed with the WARP PLS program. The study results found that there is a variable signification between the National Standard of Education on employment opportunities of vocational school graduates. Positive influence indicates that the higher/better the National Standard of Education, the higher or improved the outcome of vocational school graduates. Based on the results of the analysis indicator, the study found the NSE 8 indicator is the Education Assessment Standard which has the highest component weight value that indicates that the NSE's institutions are most important in producing graduates who are absorbed in the workforce. Then, the second-highest order is the NSE's indicative 2 and 1, namely process standards and content standard. For the indicator with the lowest value is the indicative standard educators and educational personnel and facilities and infrastructure Standard.
\end{abstract}

This is an open access article under the $\underline{\mathrm{CC}-\mathrm{BY}-\mathrm{SA}}$ license.

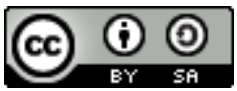

How to cite:

Andriansyah, E. H., \& Kamalia, P. U. (2021). National Standards of Education affect the emplotment opportunities of vocational high school graduates. Jurnal Pendidikan Vokasi, 11(2), 112-124.

https://doi.org/10.21831/jpv.v11i2.40791

\section{INTRODUCTION}

Vocational schools as a national education system play a very important role in creating a skilled national workforce. In essence, vocational high school graduates are expected to produce special skills-capable resources that will be expected to be a skilled workforce in their field. BPS data for 2018 explains that the largest level of Open Unemployment (TPT) among the vocational high school workforce is $11.24 \%$, an increase from the previous $8.92 \%$ in February 2018 (Alika, 2018). Based on the Badan Pusat Statistik of the Republic of Indonesia (BPS RI), it is known that the number of open unemployed in August 2019 amounted to 7.05 million people, an increase from August 2018, which was only 7 million people. Then, the Head of the Central Statistics Agency of the Republic of Indonesia, Suhariyanto, said that the open unemployment rate was dominated by vocational high school graduates of 10.42 percent in August 2019 (Badan Standar Nasional Pendidikan Republik Indonesia, 2007).

Open unemployment reflects the population who are ready to work but do not have a job. Based on previous data, it shows that vocational high schools that are expected to bring graduates ready to work still have problems. Factors of job opportunities and human resource skills still play 
an important role. This reflects the importance of the influence of secondary school education levels in contributing to unemployment in Indonesia. Vocational high school graduates are expected to be graduates who are skilled and ready to take on job market opportunities. But in fact, the level of trust in the business and industrial worlds towards vocational school graduation is still low. This was strengthened by Bamalli (2014) that the vagueness of competence achieved, a unilateral implementation that causes students not to progress in the business world/industry and do not recognize the skills obtained outside the school becomes a weakness possessed by the old vocational education.

The government has actually made policies to address these issues. Government policy in the field of education as contained in Law No. 20 of 2003 on the National Education System contains the basis and objectives of the implementation of education, compulsory learning, a guarantor of the quality of education, and the community's participation in the national education system. The policy was made to produce good Indonesian Education and qualified graduates at all levels of education. The government stipulates Government Regulation No. 19 of 2005 concerning National Education Standards and the establishment of the Badan Standar Nasional Pendidikan (BNSP) of the Republic of Indonesia as the agency that determines eight standards of educational achievement.

Based on this background, researchers are interested in discussing research on national standards of education and their benefits in outcomes for vocational high schools in Surabaya. This research aims to explain the importance of the implementation of the National Standard of Education and the need for equalization of the quality of National Standards Education at the vocational schools level in creating graduates. This is based on vocational high school graduates who have been prepared to have skills and knowledge that can later be applied to professionals in the world of work.

National Education Standards are the minimum criteria for the education system in all jurisdictions of the Republic of Indonesia (Kementerian Pendidikan Nasional Republik Indonesia, 2007) in improving the quality of human resources and measuring the education quality. This standard is not a fixed standard but is increasingly being improved. In addition, education standards also function as a quality education map. In the United States, education policy states that every student to graduate from high school is prepared for college and a career. National Education Standards discusses three kinds of variations in content/curriculum, performance standards, and student achievement (Barton, 2009). National law has mandated study programs (POS), which outline a sequence of courses aligned with secondary and post-secondary education, integrate academic, and Career and Technical Education (CTE) fields based on standards, and include workbased learning opportunities (Castellano et al., 2017).

In describing and implementing the National Education System Law No. 20 of 2003, the government issued this regulation so that the implementation of education can be in accordance with the mandate of Pancasila and the 1945 Constitution, namely good and quality education. Therefore, it is necessary first to determine the standard that should be a reference for the implementation of educational activities at the level of macro and micro. In this relationship, Government Regulation No. 19 of 2005 can be seen as an effort towards achieving this. An important thing in this Government Regulation is the need to establish an institution called the Badan Standar Nasional Pendidikan (BSNP) of the Republic of Indonesia to determine standards and criteria for achieving education delivery.

Government Regulation No. 19 of 2005 is basically a general standard for the implementation of education so that it requires operationalization in various aspects of education. Minimum standards for the provision of education as stated in article 2 of Government Regulation No. 19 of 2005, include: 1.) Content standards; 2.) Process standards; 3.) Graduate competency standards; 4.) Teachers and education staff standards; 5.) Facilities and infrastructure standards; 6.) Management standards; 7.) Financing standards; and 8.) Education assessment standards. Content Standards are the scope of materials and competency levels outlined in the criteria on graduation competencies, competencies of study materials, competencies of subjects, and learning syllabus that students must meet at certain levels and types of education. Content Standards are tailored to the substance of national educational objectives in the domain of spiritual attitudes and social attitudes, knowledge, and skills (Kementerian Pendidikan dan Kebudayaan Republik Indonesia, 2016).

Process Standards are standards related to the implementation of learning in educational units to achieve graduate competency standards. Process standards include planning the learning 
process, implementing the learning process, assessing learning outcomes, and monitoring the learning process. The overall characteristics of the learning process in senior high and vocational schools are subject-based, although the thematic approach is still maintained. Graduate Competency Standards are qualifications of graduate abilities that include attitudes, knowledge, and skills. Competency Standards for Graduates consist of criteria for qualifying students' abilities which are expected to be realized after completing their learning at school at the primary and secondary education levels. Efforts to determine the achievement and suitability of the Competency Standards for graduates and graduates from each school and the curriculum used in certain schools need to be monitored and evaluated regularly and continuously every period. These results are used as input for improving the Competency Standards for graduates in the future (Kementerian Pendidikan dan Kebudayaan Republik Indonesia, 2016).

Teachers and Education Personnel Standards are the criteria for pre-service education and physical and mental eligibility, including education in an office. Facilities and Infrastructure Standards are standards related to minimum criteria related to study rooms, sports places, places of worship, libraries, laboratories, workshops, playgrounds, recreation areas, and other learning resources needed to support the learning process, including the use of information technology and communication. Management Standards are standards related to the planning, implementation, and supervision of educational activities at the school, district/city, provincial or national level in order to achieve efficiency and effectiveness in the delivery of education.

Financing Standard is a standard that regulates the components and the amount of operating costs of educational units that are valid for one year. Education Assessment Standard is a national standard of education related to the mechanisms, procedures, and instruments of assessment of student learning outcomes (Kementerian Pendidikan Nasional Republik Indonesia, 2009). Vocational high school education is part of the education system that prepares students to be competent in one group of work or one field of work over other fields of work. This is in accordance with the mandate of the Sistem Pendidikan Nasional (Sisdiknas) Law, that vocational education is an education that prepares students to be able to work in a particular field or prepare students to enter the world of work (Kunandar, 2007). Based on the statement, vocational high schools focus on a specific skills program or educational programs tailored to the needs of the job.

Government Regulation No. 19 of 1990 concerning vocational secondary education article 3 Paragraph 2 vocational high schools prioritize the preparation of students to enter the workforce and develop professional attitudes. The meaning of the end result of vocational high schools is that graduates are ready to work with a professional attitude which will benefit the application of their skills to certain job fields. According to Decree of the Ministry of Education and Culture of the Republic of Indonesia No.001a/O/1999 concerning vocational high schools article 2 paragraph 1 , the purpose of education in vocational high schools is to prepare students to continue to higher levels of education and expand basic education; Increase the ability of students as members of the community in making reciprocal relationships with the surrounding social, cultural and natural environment; Improve the ability of students to develop themselves in line with the development of science, technology and arts and equip students to jump into the real world of work and develop professional attitudes.

The outcome is defined as a condition that reflects how much of the total workforce can be absorbed or actively participate in a country's economic activities. The understanding conveyed by some experts means that outcome is the long-term effect of the educational process, for example, achievement, acceptance to further education, further training, job opportunities, income, and further prestige (Kaluge, 2003) or participants' response to the services provided in a program; or the impact, benefits, expectations of change from an activity or service of a program. Bishop and Mane (2004) study found that most vocational high school students have significantly higher levels of school experience and higher high school graduation rates in some countries. The results also show that computer courses profoundly affect the stages eight years after they graduate. Employment opportunities can not be separated from the principle of supply and demand of workers, namely labor and labor market. Labor is everyone who is willing to be able to work (Sumarsono, 2010). While the labor market is all the activities of actors who bring together job searchers with job openings or meet the demand and supply of labor (Sumarsono, 2010) 
In requesting labor, the company will pay attention to various aspects, such as filling existing vacancies with the right human resources (Sumarsono, 2003). This means that there is a match between job vacancies and the prospective workforce's level of education and skills. When it comes to a workforce with a level of education and skills, we can distinguish between an educated and unedified workforce. The educated labor market is a labor market that requires special qualification requirements that are usually obtained through formal education and require a long time and considerable educational costs. While the unedified labor market is a job market that offers and asks for labor that does not require special qualifications and a relatively low level of education.

Vocational school curriculum should prioritize subjects related to employment and employment or as referred to as Link and Match Model that is to choose subjects and majors that can support the work. But in fact Kunandar (2007) states that educational institutions are more often fixated on theory so that students are less innovative and creative and lack competence. According to Meer's (2007), students on the vocational track would benefit from a more academically stricter education. Selection confounds attempts to decipher the effects of academics on after-secondary income.

The current trend in society shows that a person's education level does not significantly affect a person's growth but has more influence on the level of skills they have and the ability to apply these skills in the real world of work (Okolocha, 2012). To produce vocational school graduates that are in accordance with the needs of the business world (du) and the industrial world (di), which in real terms continue to develop over time, the vocational curriculum must be designed and implemented to adjust the development of science and technology. Teachers as one of the important components in the learning process should be able to choose a teaching and learning activity that sat down students, so that when students are faced with problems that exist in real life. Students can associate and seek the initial knowledge they have to solve a problem.

Several previous studies have been partially conducted, both from each indicator in the National Standard of Education, graduate learning outcomes towards employment opportunities in the world of work. Handayani (2005) research proves the influence of school facilities and infrastructure on vocational school graduates. Manalu et al. (2017) shows the influence of tuition fees on the output of students in elementary to secondary level. Akkoyunlu (2002) argues that teaching materials such as textbooks, overhead projectors, radio, films, television, video recorders, and computers enrich the learning environment in schools. Teaching materials motivate and encourage students to study subject matter while providing opportunities for students to access and explore information.

The statement about the components of National Education Standard was also strengthened by Astuti (2011) in his research which with the results of the Influence of teacher competence, learning media, and industrial business world on the quality of graduates at vocational high School 2 Wonosobo. The study examined the individual variables in the NSE as well as the output of the education unit. There has been no research combining the NSE's overall variables and the education unit's output on employment opportunities.

Department of Education Republic of Indonesia (2007), states that student learning assessment in America is needed to reach more effectively for students and to the public, Central America Commission on higher education revised accreditation standards, characteristics of excellence in higher education namely requirements and standards accreditation, to improve requirements and recommendations for setting learning goals and assessing student achievement. Assessing students from the process will assist the institution in teaching students in selecting institutions, managing their own learning, and planning and supporting students for the institution. This handbook serves as a resource for institutions looking for a bridge between the standard accreditation section and the institution as a practical daily challenge of assessment and continuous improvement.

Xiaomu et al. (2008) in their research, states that the Information Literacy Competency Standards for Higher Education in Beijing consist of seven first-level indicators (standards), nineteen second-level indicators (performance indicators), and sixty-one third-level indicators (results). The importance of making competency standards in China as a developing country is because many secondary school graduates lack information awareness.

Bonner et al. (2010) states that educational infrastructure has an important role. In this condition, the location and nature of school infrastructure affect the access and quality of education, namely the closer the schools are, the more likely they are to attend, both because of distance and 
safety issues; where the quality of infrastructure (particularly water and sanitation) is improved, enrollment and completion rates are also improved and teacher absenteeism is less, and the condition of school facilities is improved, learning outcomes are also improved. It has the greatest impact in terms of education infrastructure, which will vary from school to school. All necessary educational infrastructure facilities are essential for effective teaching and learning, such as classrooms, outdoor learning and play areas, furniture, water and sanitation, administrative buildings, storage, and facility readiness. Harahap (2009), in his research, concluded that one of the variable components of the standard of educators and educators (teachers) has no significant effect on the employment opportunities of graduates referred to as outcomes either before or after the NSE. But this is not in line with the results of Listiyani (2019), which concluded that the entrepreneurial competence of the Headmaster of Vocational High School 6 Palembang plays an important role in advancing schools.

Improving the quality of the implementation of government programs will support the progress of education in Indonesia, but the quality of education has not changed for the better. The development of education is seen from the graduation rate and the level of graduate absorption in the real world of work. According to Lynch (2000), there are 4 (four) forces that support the reform of secondary school vocational education in the United States, namely the new economy, public expectations for schools, new research on student learning and motivation, and secondary school reform. Six integral components for reform: secondary school, elementary and contextual learning, work-based learning, authentic production, career academy, and technology preparation.

The results of Elfitri et al. (2019) show: 1.) Content standards and standards have a positive and significant effect on national exam scores; 2.) Teacher and education staff standards have a positive and significant effect on the number of vocational high school graduates who are accepted to work in the business or industrial world; 3.) Process standards have a negative and significant effect on the number of vocational high school graduates who are accepted to continue their education in tertiary institutions; and 4.) Graduate competency standards, facility standards, management standards and management quality and the quality of vocational high school graduates. This means that other factors affect the academic quality of vocational middle school graduates, such as the parents' background, motivation, and interests of the students themselves.

\section{RESEARCH METHOD}

This study was conducted to analyze the indicators of National Standards of Education and Education unit output that is dominant against the work of vocational school graduates in Surabaya. This study is classified into ex-post factor type of research because researchers do not give treatment or manipulate specific changes of the study subjects. The data used is available without having to perform a data search. This ex post facto research method was carried out to examine the events that occurred and reduce to find out the factors that could lead to the occurrence of these events (Riduwan, 2013).

The researchers' design is done with a descriptive quantitative approach to know the signification of the influence of the national standard of education applied by public vocational secondary schools and private expertise group economy/accounting to the employment opportunities of vocational students in the city of Surabaya. The data analyzed in this study is primary data equipped with secondary data obtained from the Surabaya Education Office, each school's data that becomes the object of research, and other relevant data. Data processing is done with the PLS program. The primary data source is the National Standard of Education data obtained from the National Education Standards Agency of East Java Province in the form of the value of each indicator National Standard of Education. Then, secondary data is obtained from the spread of questionnaires about the absorption rate of graduates of each vocational school of Surabaya.

The population of this research is all vocational high schools both state and private in Surabaya, which has majored in economics or accounting and finance vocational high School in Surabaya. The sampling technique in this study is purposive sampling. Purposive sampling is a sampling technique with certain considerations (Sugiyono, 2013). In this study, sampling determination using considerations as follows: 1.) The sample is a public and private vocational school with majors in marketing, office administration, accounting, and banking considering the background of 
researchers in economics and accounting; 2.) Samples are based on the availability of primary data in the field, especially vocational schools that have been accredited in the National Accreditation Board For School and Madrasah, to obtain valid source data; and 3.) The data of graduate years 2014 and 2015 was selected based on the availability of employment opportunity data of graduate students recorded in the school is the data of graduate students two years earlier. Based on the initial observations, the school takes approximately 1-2 years to obtain data of students who have worked.

The research is trying to link NSE variables to employment opportunities. This study consists of independent variables, namely variable National Standard of Education and graduate outcomes. In accordance with Government Regulation No. 19 of 2005, the measurement for the national standard of education as much as 8 (eight) namely NSE 1, content standards; NSE 2, standard process; NSE 3, graduate competency standards; NSE 4, standards of educators and education workers; NSE 5 standard of facilities and infrastructure; NSE 6, management standards; NSE 7, funding standards; and NSE 8, assessment standards. The measurement uses document data from National Professional Certification Agency in the form of values 10-100.

Then for graduate work is a field or type of work that is able to provide opportunities for someone to do activities to generate wages (salary). Measurement of employment opportunities graduates is reflected by the variable manifest/indicator, the percentage of the number of graduate students absorbed in the world of work. The data generated on the variables above are data in the form of an average assessment range of 10-100 for the National Education Standards and a percentage of $10-100 \%$ for graduate employment opportunities.

This study used data analysis techniques using Structural Equation Modeling (SEM) analysis using PLS (Partial Least Square) through WarpPLS application. The data analysis in this study uses descriptive and inferential statistics pls (Partial Least Square) and is equipped with simple correlation because the sample does not meet the minimum recommended size (100-200), then can use an alternative method sem, namely partial least square (PLS), namely SEM-based components or variance. PLS is non-parametric and is not bound by the assumption of data that must be distributed normally in a multivariate manner or the need for many samples (Latan \& Ghozali, 2015).

The reasons for using PLS analysis in this study are: 1.) This model does not assume a certain distribution of data which can be in the form of nominal, category, ordinal, interval, or ratio; 2.) The variables used in the study are latent variables; 3.) The entire population of SMKs in Surabaya is used as a sample, but the number is small $(\mathrm{n}<100)$, so it does not meet when using SEM analysis (Structural Equation Model), and the size of the sample enters intervals of 30 to 100 as recommended by PLS; and 4.) Ability to overcome LVs (latent variables) that cannot be measured directly but that require measurement of models consisting of one or many indicators (Urbach \& Ahlemann, 2010). Evaluation of models in PLS-SEM using the WarpPLS program can be done by assessing the results of model measurement (measurement model). Steps in analysis WarpPLS (Solimun et al., 2017).

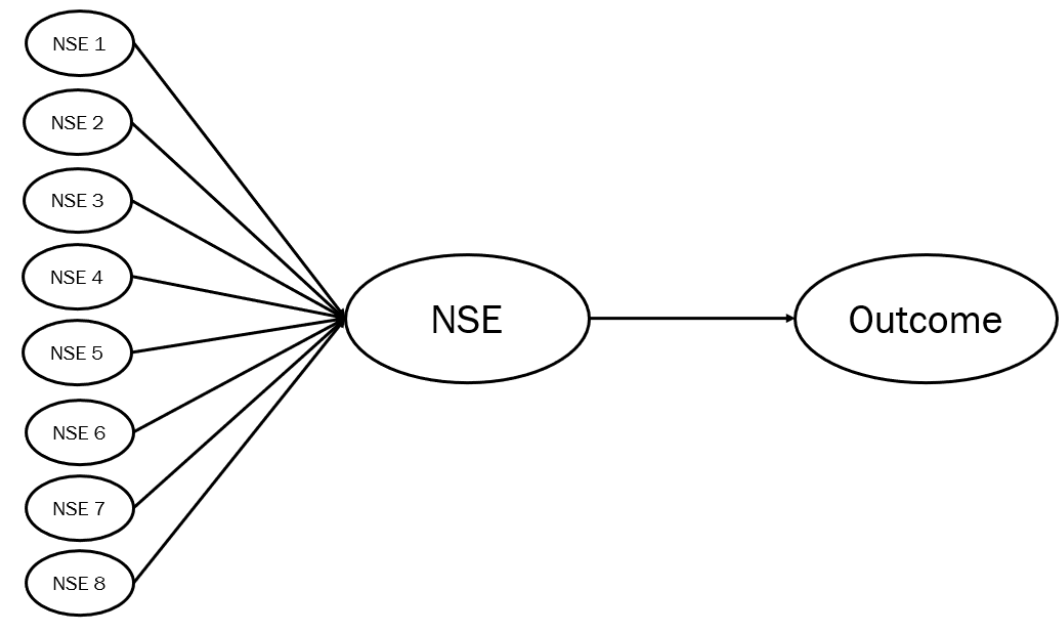

Figure 1. Model Path 


\section{RESULT AND DISCUSSION}

Based on the results of the analysis of fit and quality indices model as a whole produces calculation results that meet the criteria of both APC, ARS, AARS, AVIF, AFVIF, GoF with medium criteria, SPR, RSCR, SSR, and NLBCDR, which all meet the criteria, this means the level of a good relationship between latent variables (inner model) both overall. In this study, one hypothesis is proposed to test the direct influence between NSE variables on outcome variables. Hypothesis testing on WarpPLS analysis basically tests the significance of the coefficient of pathways present in the research model. The test results of the path coefficient are presented in the following tables 3 and 4 .

Based on the results of data analysis using WarpPLS, there is an influence of variable $\mathrm{X}$ on variable $Y$ with a coefficient of the path of 0.609 and $p<0.001$. Since $P$ is smaller than 0.01 , it can be said to have a significant effect on the level of error of $1 \%$, so the hypothesis is accepted. A positively marked line coefficient of 0.609 indicates that the better/higher the National Standard of Education, the Y increases with a greater influence of $60.9 \%$.

\section{Conditions of National Standard of Education Vocational High School}

Table 1 is data processed by researchers taken from the results of assessments conducted by BAN / SM for 22 vocational management and business schools in the city of Surabaya. Based on the value obtained, a value shows the average value of each component of the National Standard of Education. The average content standard value shows a value of 83 , process standard with a value of 82 , graduate competency standard with a value of 80 , standard educators and educational personnel with a value of 78, Standard Facilities and Infrastructure with a value of 77, management standard 79 , financing standard with a value of 84 and, education assessment standard with a value of 82 . the results of the assessment showed the average value of the eight components of the NSE could be said good, in general vocational high school majoring in business and management in the city of Surabaya has implemented components in the NSE well.

Table 1. Assessment of Components of National Standard of Vocational Education business and management

\begin{tabular}{clc}
\hline No. & NSE & Average \\
\hline 1. & Standard Content & 83 \\
2. & Process Standards & 82 \\
3. & Graduate Competency Standards & 80 \\
4. & Standards of Educators and Educators & 78 \\
5. & Standard Facilities and Infrastructure & 77 \\
6. & Management Standards & 79 \\
7. & Financing Standards & 84 \\
8. & Education Assessment Standards & 82 \\
\hline
\end{tabular}

(Source: Data processed researchers)

Outcome Condition (Graduates Absorbed in the World of Work) Vocational high School

The education outcome unit is used as a research object as a variable that is affected by the National Standard of Education variable. The output in question is the number of graduates of vocational high schools in Surabaya who are absorbed in the world of work. Data from the Ministry of Education and Culture in 2017 stated that there are 105 public and private vocational schools in Surabaya. The number of vocational schools filters the number registered as National Accreditation Board for Schools and Madrasas accredited schools in East Java Province in 2014 - 2015 and research restrictions on vocational schools with departments of Management and Business so that a total of 22 state and private vocational schools are filtered as research objects.

A vocational high school is a school that is built or established to create graduates ready to work according to their interests and talents. Proof of readiness of vocational schools in the city of Surabaya has provided a special section called BKK (Special Work Guidance), which is in charge of recording and providing information and even providing employment to students who have 
graduated in the vocational school. This is in accordance with the statement of Government Regulation No. 29 of 1990 concerning middle education chapter I article 1 paragraph 3 states that vocational secondary education is an education at the secondary level that prioritizes the development of students' ability to carry out certain types of work. Although vocational high school was formed to build an independent person and ready to plunge into the world of work, in fact, graduates still choose to continue to a higher level of education, namely higher education.

\section{Descriptive Quantitative Analysis Results}

Data collection techniques for variables of National Standard of Education using primary data obtained from the National Accreditation Board of Secondary Schools of East Java Province, while data collection techniques for graduate outcomes are obtained from the results of written interviews through the dissemination of questionnaires to the intended school. Surabaya is the second-largest city after Jakarta. Surabaya city government is sensitive to the importance of education for its people. Proven in 2015 Surabaya city government implemented compulsory learning for 12 years that ratified the school up to the level of high school or vocational school. In 2016, there were 102 vocational high schools recorded in Surabaya, both public and private.

Based on the results of tabulation of NSE variable data with average methods, it can be described that the average school that is the object of research has a good condition of National Standard of Education. The NSE's condition in schools that are already good is the School Condition with National Standards of Educators and on Standards 1 (content standards), Standards 2 (process standards), Standards 7 (financing standards), and Standards 8 (educational assessment standards).

The condition of the National Standard of Education in schools is best in the 7th Standard, namely financing standards. The NSE's condition in schools is the lowest in Standard 4 (standard educators and educational personnel), then standard 5 (standard facilities and infrastructure). The findings are very contrary to what should be, considering the importance of human resources (educators and education) as the subject of processing raw materials and infrastructure as containers and supporting resources in processing the students to be ready to compete in the outside world later so that both standards need to be improved even better.

On the average value of graduate outcome data is still seen graduates with the absorption of the world of work in accordance with the majors taken by the majority below $50 \%$. Based on the results of field observations found that the average vocational school students generally school in the middle of the city choose to continue their education to higher education while vocational schools in the suburbs prefer to work directly. This is because graduates have now started to think openly about the demands of education in the world of work, such as the level of education that will determine their position in work.

Graduates who choose to continue to higher education with adequate financial support so as to support their decision, while suburban school graduates with the majority of middle and lower economic students prefer to work despite their desire to continue to higher education but because of financial limitations so that work is the right choice to later be used as capital to continue to higher education.

The Influence of National Standards of Education on Employment Opportunities of Vocational School Graduates

The National Education Standard was established to equalize the quality and quality of schools in an effort to reduce the gap between schools. In fact, the implementation of the National Standard of Education is intended for public schools and private schools. Such efforts allow for no quality gap between public and private schools, suburban schools, and middle-of-town schools.

Hypothesis testing shows a significant influence of The National Standard of Education on the employment opportunities of vocational school graduates in the city of Surabaya. The results of this study indicate the importance of standards that become a reference for the implementation of educational activities at a small-scale level of large DNA as stated in the National Education System Law No. 20 of 2003, so that the implementation of education can be in accordance with Pancasila and the 1945 Constitution, namely good and quality education. 
This research reinforced the research of Xiaomu et al. (2008), Harahap (2009), Bonner et al. (2010), and the Department of Education Republic of Indonesia (2007) which resulted in the conclusion that the National Standard of Education directly affects graduate employment opportunities even though the research was conducted partially in the NSE component. Department of Education Republic of Indonesia (2007), states the Characteristics of Excellence in higher education, namely the requirements and Standards of Accreditation of Higher Education, to improve the requirements and recommendations in setting learning objectives and assessing student achievement. The characteristics of excellence can be seen from how the college manages the management of the institution well.

Research by Marquez-Zenkov et al. (2007) concluded that the quality of teachers was not sufficient in producing quality and competitive student output in the world of work. There needs to be a government regulation that regulates the curriculum according to regional potential. This type of evaluation is tailored to the curriculum used with the Teacher's license program, which is based on the concept of socially just leadership and a portfolio assessment system. So there needs to be a relationship between the quality of educators and management of education management.

Consistent with the study of Nastiti and Wahjusaputri (2019), which states that the quality of national education is not sufficient to produce quality outcomes for students, adequate school facilities are needed in the form of facilities and infrastructure, appropriateness of teaching methods, curricula and government policies in education. As in Indonesia, Harahap (2009) strengthens through his research regarding the direct relationship between the National Education Standards and employment opportunities, explaining that apart from teachers and education personnel, it is necessary to match the components of facilities and infrastructure, financing in producing the desired graduate job opportunities.

Several previous studies have shown the importance of educational standards in managing schools for equalizing the quality of the school in the same mission vision to achieve the goal of vocational high school, which is to create graduates who are creative, independent, and ready to compete in the world of work.

Analysis of National Standards of Education Indicators on the Outcome

Table 2 shows the NSE 8 indicator has the highest component weight value with a value of 0.953. This indicates that the most important indicator of the National Standard of Education in producing graduates absorbed in the world of work is the Education Assessment Standard. Empirically the average value of standard 8 is that the assessment of education also falls into the category of good, so it is recommended to be maintained.

Table 2. NSE Variable Profile (X)

\begin{tabular}{ccccc}
\hline No. & Indicators & Component Weight & Average (Empirical Condition) & Advice \\
\hline 1 & NSE 1 & 0.908 & 83,37 & Maintained \\
2 & NSE 2 & 0.932 & 82,42 & Maintained \\
3 & NSE 3 & 0.896 & 79,80 & Improved \\
4 & NSE 4 & 0.859 & 77,63 & Upgraded Soon \\
5 & NSE 5 & 0.854 & 77,41 & Upgraded Soon \\
6 & NSE 6 & 0.833 & 79,25 & Improved \\
7 & NSE 7 & 0.751 & 84,54 & Maintained \\
8 & NSE 8 & 0.953 & 82,30 & Maintained \\
\hline
\end{tabular}

This indicates that in general vocational high schools in the city of Surabaya have met the standards of educational assessment in accordance with the rules set by the government, namely to meet the principles, among others: objective, valid, fair, integrated, open, thorough and sustainable, systematic, based on criteria, and accountable. This principle is considered very important in evaluating the results of reasoning knowledge obtained by vocational high school students to prepare them for self-study in the world of work. In general, the assessment of vocational school students in 
Surabaya refers to assessments with contextual activities prepared by the school, for example, banking practices, trade cooperatives, all of which are faced with real work assessments.

The second high position level occupied NSE indicators 2 and 1, namely process standards and content standards. Process standards include planning the learning process, implementation of the learning process, assessment of learning outcomes, and supervision of the learning process to implement an effective and efficient learning process. While the standard of material content is minimal and the level of competence is minimal to achieve the competence of graduates at a minimum at a certain level and type of education (Kementerian Pendidikan Nasional Republik Indonesia, 2006).

In value, the weight of the components of both indicators is worth 0.932 and 0.902 with empirical values at an average of 8 . This indicates that it is necessary to maintain these indicators to create graduate students who can be absorbed in the world of work. Empirically these three highest indicators are interrelated. Good educational assessment can be carried out by the existence of a good standard of the process that is through supervision of the learning process and must pay attention to the minimum content standards that each student in the vocational school must own.

These results are in line with Allejar (2017) research on the importance of process standards in producing learning effectiveness. Implementing the Education Process Standard Policy has a positive and significant effect on curriculum management to realize the effectiveness of learning. The results of hypothesis testing show a relatively large influence. Empirically, this hypothesis test provides an idea that the implementation of optimal Education Process Standard Policy and the existence of good curriculum management can influence the realization of learning effectiveness.

In other indicators with the lowest value that needs to be improved, especially in the NSE 4 indicator, namely the standard of educators and educational personnel and standard 5, namely facilities and infrastructure. Both indicators in the results of the data processing of this study are considered less instrumental in increasing the number of graduates absorbed in the world of work empirically. Human resources are an important key in processing and processing students to be able to become products and infrastructure facilities as facilities to support teachers as containers and tools to create students who are ready to be independent and competitive in the world of work.

The results are in accordance with the research of Bonner et al. (2010) on the importance of facilities and infrastructure in his research stated the importance of Educational Infrastructure Facilities. In line with the research of Ramadhan dan Soenarto (2015) stated in his research that facilities and infrastructure are factors that affect the learning achievement of vocational school students. High student learning achievement will improve the quality of students both knowledge and skills that will be able to compete in the world of work.

\section{CONCLUSION}

Based on the results of data analysis, it can be concluded that there is a significant influence between the National Education Standards on the outcomes of vocational schools graduates in Surabaya. The results of this research indicator analysis found that the SNP 8 indicator has the highest component weight value, which indicates that the most important indicator of National Education Standards in producing graduates who are absorbed in the world of work is the Education Assessment Standard. Then the next highest order is the SNP 2 and 1 indicators, namely process standards and content standards. The indicator with the lowest score is the SNP 4 indicator, namely standard for teachers and eucation personnel and standard 5, facilities and infrastructure. The two indicators are considered to have less role in increasing the number of graduates who are absorbed in the world of work empirically, but that does not mean they are not important, so they need to be improved.

\section{REFERENCES}

Akkoyunlu, B. (2002). Educational technology in Turkey: Past, present and future. Educational Media International, 39(2), 165-174. https://doi.org/10.1080/09523980210155352 
Alika, R. (2018). Mendikbud lihat lulusan SMK banyak menganggur karena masalah industri. Katadata.Com. https://katadata.co.id/marthathertina/finansial/5e9a5598a6f9e/mendikbudlihat-lulusan-smk-banyak-menganggur-karena-masalah-industri

Allejar, M. (2017). Pengaruh implementasi kebijakan standar proses pendidikan terhadap manajemen kurikulum untuk mewujudkan efektivitas pembelajaran. Khazanah Akademia, l(1), 39-48. https://core.ac.uk/reader/249324700

Astuti, A. N. F. (2011). Pengaruh kompetensi guru, media pembelajaran, dan dunia usaha dunia industri terhadap mutu lulusan di SMK 2 Wonosobo [Universitas Muhammadiyah Surakarta]. http://eprints.ums.ac.id/id/eprint/15058

Badan Standar Nasional Pendidikan Republik Indonesia. (2007). Standar pendidik dan tenaga kependidikan. Bsnp-Indonesia.Org. https://bsnp-indonesia.org/standar-pendidikan-dantenaga-kependidikan/

Bamalli, H. S. (2014). Competencies and strategies for the teaching of 21 st century learners in vocational home economics education. International Letters of Social and Humanistic Sciences, 19(8), 50-55. https://doi.org/10.18052/www.scipress.com/ILSHS.19.50

Barton, P. E. (2009). National education standards: Getting beneath the surface. Educational Testing Service. https://eric.ed.gov/?id=ED507800

Bishop, J. H., \& Mane, F. (2004). The impacts of career-technical education on high school labor market success. Economics of Education Review, 23(4), 381-402. https://doi.org/10.1016/j.econedurev.2004.04.001

Bonner, R., Das, P. K., Kalra, R., Leathes, B., \& Wakeham, N. (2010). Delivering cost effective and sustainable school infrastructure. TI-UP Resouce Center. https://inee.org/system/files/resources/del-cost-eff-sust-sch-infra1.pdf

Castellano, M. E., Richardson, G. B., Sundell, K., \& Stone, J. R. (2017). Preparing students for college and career in the United States: The effects of career-themed programs of study on high school performance. Vocations and Learning, 10(1), 47-70. https://doi.org/10.1007/s12186-016-9162-7

Departemen Pendidikan Nasional Republik Indonesia. (2007). Teropong wajah sekolah menengah kejuruan di Indonesia: Buklet sekolah menengah kejuruan. Direktoral Pembinaan Sekolah Menengah Kejuruan.

Elfitri, R., Muchtar, B., \& Evanita, S. (2019). The effect of National Education Standards on academic quality of graduates vocational high school in Solok City and Regency. Proceedings of the 2nd Padang International Conference on Education, Economics, Business and Accounting (PICEEBA-2 2018), 873-880. https://doi.org/10.2991/piceeba218.2019.111

Handayani, B. (2005). Pengaruh tingkat pendidikan, sarana prasarana dan lingkungan kerja terhadap kinerja guru di SMA Negeri 1 Karangdowo [Universitas Muhammadiyah Surakarta]. http://eprints.ums.ac.id/id/eprint/7012

Harahap, S. S. (2009). Pengaruh penerapan Standar Nasional Pendidikan terhadap kesempatan kerja lulusan siswa SMK Negeri di Kota Medan [Universitas Sumatera Utara]. http://repositori.usu.ac.id/handle/123456789/35043

Kaluge, L. (2003). Sendi-sendi manajemen pendidikan. Unesa University Press.

Kementerian Pendidikan dan Kebudayaan Republik Indonesia. (1999). Keputusan Menteri Pendidikan dan Kebudayaan Republik Indonesia Nomor 001a/O/1999 tentang Pembukaan dan Pengegerian Sekolah Tahun Pelajaran 1997/1998. Kementerian Pendidikan dan Kebudayaan Republik Indonesia. http://vervalsp.data.kemdikbud.go.id/verval/dokumen/skoperasional/39440918.pdf 
Kementerian Pendidikan dan Kebudayaan Republik Indonesia. (2016). Peraturan Menteri Pendidikan dan Kebudayaan Republik Indonesia Nomor 21 Tahun 2016 tentang Standar Isi Pendidikan Dasar dan Menengah. Kementerian Pendidikan dan Kebudayaan Republik Indoensia. $\quad$ https://bsnp-indonesia.org/wpcontent/uploads/2009/06/Permendikbud_Tahun2016_Nomor021_Lampiran.pdf

Kementerian Pendidikan Nasional Republik Indonesia. (2006). Peraturan Menteri Pendidikan Nasional Republik Indoensia Nomor 22 Tahun 2006 tentang Standar Isi untuk Satuan Pendidikan Dasar dan Menengah. Kementerian Pendidikan Nasional Republik Indonesia. https://jdih.kemdikbud.go.id/arsip/permen_tahun2006_nomor22.pdf

Kementerian Pendidikan Nasional Republik Indonesia. (2007). Peraturan Menteri Pendidikan Nasional Republik Indoensia Nomor 19 Tahun 2007 tentang Standar Pengelolaan Pendidikan oleh Satuan Pendidikan Dasar dan Menengah. Kementerian Pendidikan Nasional Republik Indonesia. https://simpuh.kemenag.go.id/regulasi/permendiknas_19_07.pdf

Kementerian Pendidikan Nasional Republik Indonesia. (2009). Peraturan Menteri Pendidikan Nasional Republik Indonesia Nomor 69 Tahun 2009 tentang Standar Biaya Pendidikan Dasar dan Menengah. Kementerian Pendidikan Nasional Republik Indonesia. https://simpuh.kemenag.go.id/regulasi/permendiknas_69_09.pdf

Kunandar, K. (2007). Guru profesional implementasi Kurikulum Tingkat Satuan Pendidikan (KTSP) dan sukses dalam sertifikasi guru (1st ed.). RajaGrafindo Persada.

Latan, H., \& Ghozali, I. (2015). Partial least squares: Concepts, techniques, and applications using SmartPLS 3. Badan Penerbit Universitas Diponegoro.

Listiyani, L. (2019). Hubungan antara dukungan sosial orang tua dengan kepercayaan diri. Journal for Lesson and Learning Studies, 2(1), 10-20. https://doi.org/10.23887/jlls.v2i1.17315

Lynch, R. (2000). High school career and technical education for the first decade of the 21 st century. Journal of Vocational Education Research, 2, 155-198. https://www.researchgate.net/publication/240617635_High_School_Career_and_Technical _Education_for_the_First_Decade_of_the_Twenty-First_Century

Manalu, S. R. I., Hermanto, S., Duling, J. R., Siswandi, G., Supriyadi, S., \& Siahaan, A. P. (2017). Tata kelola pelaksanaan: Teaching factory. Direktorat Pembinaan Sekolah Menengah Kejuruan, Kementerian Pendidikan dan Kebudayaan Republik Indonesia. http://smk.kemdikbud.go.id/uploads/filestorage/12T6YhfmJdfx9omMxkIznZN0wUhQ3gI7 hcfayTlE.pdf

Marquez-Zenkov, K., Harmon, J., van Lier, P., \& Marquez-Zenkov, M. (2007). If they'll listen to us about life, we'll listen to them about school: Seeing city students' ideas about 'quality' teachers. Educational Action Research, 15(3), 403-415. https://doi.org/10.1080/09650790701514457

Meer, J. (2007). Evidence on the returns to secondary vocational education. Economics of Education Review, 26(5), 559-573. https://doi.org/10.1016/j.econedurev.2006.04.002

Nastiti, T. I., \& Wahjusaputri, S. (2019). Knowledge sharing practices in academics. In Y. Badrun \& E. Fuad (Eds.), The 4th International Conference on Communication, Economics, Education, Law, Science and Technology (CELSciTech) (Vol. 4, pp. 5-8). The Institute for Research and Community Service Universitas Muhammadiyah Riau. https://ejurnal.umri.ac.id/index.php/PCST/article/view/1727

Okolocha, C. C. (2012). Vocational technical education in Nigeria: Challenges and the way forward. Business Management Dynamics, 2(6), 1-8. https://www.proquest.com/openview/6926964aeb532306737613ad41309637/1?pqorigsite $=$ gscholar $\&$ cbl $=2050645$ 
Presiden Republik Indonesia. (1990). Peraturan Pemerintah Republik Indonesia Nomor 29 Tahun 1990 tentang Pendidikan Menengah. http://www.bphn.go.id/data/documents/90pp029.pdf

Presiden Republik Indonesia. (2003). Undang-Undang Republik Indonesia Nomor 20 Tahun 2003 tentang Sistem Pendidikan Nasional. http://simkeu.kemdikbud.go.id/index.php/peraturan1/8-uu-undang-undang/12-uu-no-20tahun-2003-tentang-sistem-pendidikan-nasional

Presiden Republik Indonesia. (2005). Peraturan Pemerintah Republik Indonesia Nomor 19 Tahun 2005 tentang Standar Nasional Pendidikan.

Ramadhan, A. N., \& Soenarto, S. (2015). Pengaruh persepsi siswa terhadap faktor-faktor yang mempengaruhi prestasi belajar teori kejuruan siswa SMK. Jurnal Pendidikan Vokasi, 5(3), 297-312. https://doi.org/10.21831/jpv.v5i3.6485

Riduwan, R. (2013). Belajar mudah penelitian untuk guru-karyawan dan peneliti pemula. Alfabeta.

Solimun, S., Fernandes, A. A. R., \& Nurjannah, N. (2017). Metode statistika multivariat pemodelan persamaan kultural. UB Press.

Sugiyono, S. (2013). Metode penelitian pendidikan: Pendekatan kuantitatif, kualitatif, dan $R \& D$ (17th ed.). Alfabeta.

Sumarsono, Sonny. (2003). Ekonomi manajemen sumberdaya manusia dan ketenagakerjaan (1st ed.). Graha Ilmu.

Sumarsono, Sumarsono. (2010). Kewirausahaan. Graha Ilmu.

Urbach, N., \& Ahlemann, F. (2010). Structural equation modeling in information systems research using partial least squares. Journal of Information Technology Theory and Application, 11(2), 5-40. https://aisel.aisnet.org/jitta/vol11/iss2/2

Xiaomu, Z., Ping, S., Mengli, W., \& Weichun, D. (2008). Delphi research on information literacy competency standards for higher education in Beijing, China. Chinese Librarianship: An International Electronic Journal, 29, 1-13. http://www.iclc.us/cliej/cl25ZSWD.pdf 